DOI: https://doi.org/10.47405/mjssh.v6i10.1111

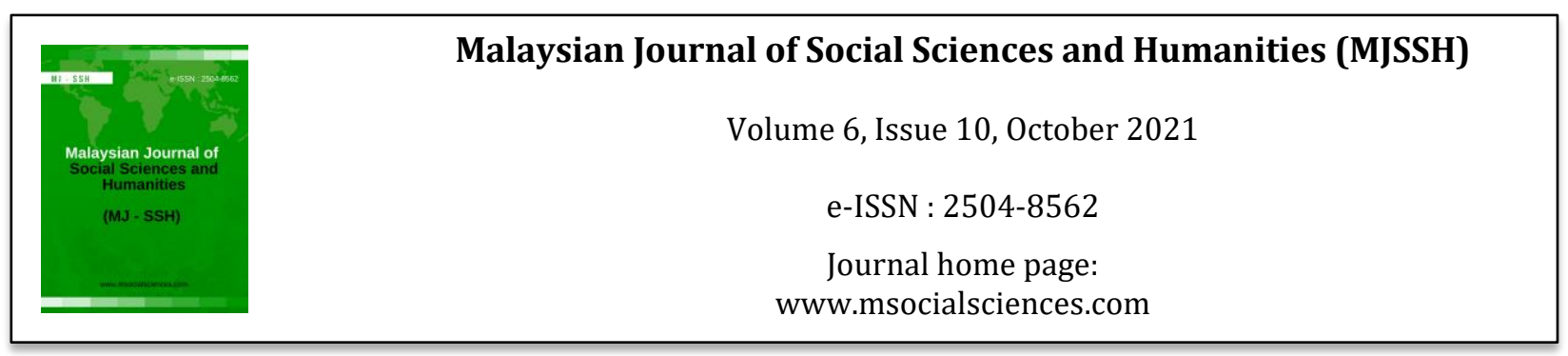

\title{
Pengaruh Pengurusan Disiplin Sekolah, Tingkah Laku Buli Murid dan Estim Kendiri Murid Terhadap Kualiti Kehidupan Murid: Suatu Pemerhatian Awal
}

\author{
Sire Etum ${ }^{1}$, Al-Amin Mydin ${ }^{1}$, Abdul Ghani Kanesan Abdullah' ${ }^{1}$ \\ 1Pusat Pengajian Ilmu Pendidikan, Universiti Sains Malaysia (USM), Malaysia \\ Correspondence: Sire Etum (drsireetum@student.usm.my)
}

\begin{abstract}
Abstrak
Kajian ini membincangkan pengaruh pengurusan disiplin sekolah, tingkah laku buli murid dan estim kendiri murid terhadap kualiti kehidupan murid. Pengurusan disiplin sekolah merupakan aspek yang penting dalam memastikan kehidupan murid lebih berkualiti tinggi. Setiap sekolah mempunyai sistem peraturan masing-masing yang diwujudkan bagi membendung masalah disiplin para murid. Sungguhpun begitu, murid sering mempamerkan tingkah laku yang negatif walaupun peraturan sudah ditetapkan. Matlamat Kementerian Pendidikan Malaysia (KPM) juga adalah untuk memupuk modal insan dengan kualiti, disiplin, moral, etika, daya saing dan keseimbangan dalam aspek fizikal, mental, intelektual dan sosial. Sekolah bertanggungjawab untuk merealisasikan hasrat Kementerian ini. Konteks kajian ini berfokus kepada keempat-empat variabel iaitu pengurusan disiplin murid sekolah, tingkah laku buli murid, estim kendiri murid, dan kualiti kehidupan murid juga merupakan variabel bebas dalam kajian yang mana terdapat satu dimensi iaitu pembuli. Kualiti kehidupan pula menjadi variabel bersandar dan variabel mediator dalam kajian ini pula ialah estim kendiri murid. Oleh itu, kajian ini akan menganalisis segala konsep yang berkaitan dengan keempat-empat pemboleh ubah tersebut menggunakan sorotan kajian lepas daripada pelbagai bidang yang berkaitan.
\end{abstract}

Kata kunci: pengurusan disiplin sekolah, kualiti kehidupan murid, tingkah laku buli, estim kendiri murid

\section{The Influence of School Discipline Management, Bullying Behavior Student and Student Self -Esteem on Student Quality of Life: A Preliminary Observation}

\begin{abstract}
This study discusses the influence of school discipline management, student bullying behavior and student self -esteem on student quality of life. The management of school discipline is an important aspect in ensuring a higher quality of student life. Each school has its own system of rules created to curb the disciplinary problems of students. Even so, students often exhibit negative behaviors even when rules have been set. The goal of the Ministry of Education Malaysia (MOE) is also to cultivate human capital with quality, discipline, morals, ethics, competitiveness and balance in physical, mental, intellectual and social aspects. Schools are responsible for realizing the aspirations of this Ministry. The context of this study focuses on the four variables, namely the management of school discipline, bullying behavior, student self-esteem, and quality of life of students are also independent variables in the study where there is one dimension that is bullying. Quality of life is a dependent variable and the
\end{abstract}


mediator variable in this study is students' self -esteem. Therefore, this study will analyze all the concepts related to the four variables using the highlights of past studies from various related fields.

Keywords: school discipline management, student quality of life, student behavior, student self

\section{Pengenalan}

Matlamat Kementerian Pendidikan Malaysia (KPM) adalah untuk memupuk modal insan dengan kualiti, disiplin, moral, etika, daya saing dan keseimbangan dalam aspek fizikal, mental, intelektual dan sosial. Sekolah bertanggungjawab untuk menyatakan hasrat kementerian (Zakaria et al., 2012). Selain berusaha keras untuk memastikan hasrat ini dapat direalisasikan, sekolah juga memainkan peranan penting dalam memelihara diri dan menggerakkan potensi pelajar untuk menjadi tonggak negara. Walau bagaimanapun, proses pembangunan modal insan tidak mudah kerana negara ini menghadapi pelbagai masalah yang sering menghalang perancangan tersusun.

Dasar pendidikan Malaysia hari ini berdasarkan Falsafah Pendidikan Kebangsaan (FPK) yang terkandung dalam Dasar Pendidikan Nasional (DPK), yang diperbaharui dan diperbaiki pada tahun 2012. DPK pertama berdasarkan Deklarasi Bahasa (1956) dalam Peraturan Pendidikan (1957) dan Laporan Rahman Talib (1960) yang terkandung dalam Undang-Undang Pendidikan (1961). Dasar ini kemudian dikaji oleh Jawatankuasa Kabinet pada tahun 1979, dan Undang-Undang Pendidikan 1996 [Akta 550] kemudian diumumkan untuk memungkinkan sistem pendidikan memperoleh pengetahuan, kemahiran, dan nilai-nilai yang diperlukan dalam dunia global yang sangat kompetitif. Perkembangan sains, teknologi dan maklumat dengan pantas.

Dalam FPK, pendidikan di Malaysia digariskan sebagai usaha berterusan untuk mengembangkan potensi peribadi secara menyeluruh dan bersepadu untuk mewujudkan insan yang seimbang dan harmoni dari segi kecerdasan, semangat, emosi dan badan berdasarkan iman dan kepatuhan kepada Tuhan. adalah untuk memupuk rakyat Malaysia yang berpengetahuan, bertanggungjawab dan mampu mencapai kesejahteraan diri dan menyumbang kepada keharmonian dan kemakmuran masyarakat dan negara (Kementerian Pendidikan Malaysia, 2017).

Dalam proses merealisasikan DPN dan FPK, KPM, sebagai peneraju dasar pendidikan nasional, mempunyai tanggungjawab untuk memastikan visi pendidikan nasional "pendidikan berkualiti, mendidik rakyat, dan kemakmuran negara" dan misi "menjaga pembangunan sistem pendidikan berkualiti tinggi ". Potensi individu untuk memenuhi aspirasi nasional dapat direalisasikan sesuai keperluan. Di samping itu, dengan usaha dan kerjasama semua warga negara, Kementerian Pendidikan juga bertanggung jawab untuk menentukan bahawa empat (4) tujuan pendidikan nasional dapat dicapai, iaitu untuk melahirkan bangsa Malaysia yang setia dan bersatu padu: orang kaya; menyediakan sumber manusia untuk keperluan pembangunan negara; dan menyediakan peluang pendidikan untuk semua warganegara Malaysia (Kementerian Pendidikan Malaysia, 2017).

Dalam proses merealisasikan NUP dan FPK, sebagai peneraju dasar pendidikan nasional, KPM mempunyai tanggungjawab untuk memastikan visi pendidikan nasional "pendidikan berkualiti, mendidik rakyat, dan memperkaya negara" dan misi "mengekalkan pembangunan". Sistem pendidikan berkualiti tinggi". Potensi individu untuk memenuhi aspirasi nasional dapat direalisasikan sesuai keperluan. Di samping itu, dengan usaha dan kerjasama semua warga negara, Kementerian Pendidikan juga memiliki tanggungjawab untuk memastikan bahawa empat (4) tujuan pendidikan nasional dicapai, iaitu untuk melahirkan negara Malaysia yang setia dan bersatu padu; orang kaya; menyediakan sumber manusia untuk keperluan pembangunan negara; dan memberi peluang pendidikan untuk semua warganegara Malaysia (Kementerian Pendidikan Malaysia, 2017).

Pelan Pembangunan Pendidikan Malaysia (PPPM) 2013-2025 adalah panduan dan tonggak utama untuk pengurusan sistem pendidikan negara. PPPM adalah rancangan reformasi dasar pendidikan, melalui penyelidikan dan pelaksanaan yang mendalam melalui proses transformasi sistem pendidikan 
yang ada, yang bertujuan untuk menyediakan para pelajar di negara ini dengan semua kemahiran baru yang setara dengan standard pendidikan antarabangsa dan mempersiapkan pelbagai peluang. Hadapi cabaran abad ke-21. Rancangan ini menggariskan visi sistem pendidikan dan keinginan individu pelajar yang perlu dipenuhi untuk memenuhi keperluan masa depan negara.

Kementerian Pendidikan akan sepenuhnya melaksanakan sebelas (11) transformasi utama yang terdiri daripada strategi dan operasi untuk mengubah sistem pendidikan nasional dan mewujudkan visi dan aspirasi 13 tahun, iaitu, kualiti, keadilan, perpaduan, dan kecekapan dengan mencapai hasil dalam pendaftaran. Selain menumpukan pada kejayaan sistem pendidikan, setiap pelajar juga harus mempunyai tahap kualiti yang seimbang dalam pengetahuan, kemahiran berfikir, kemahiran kepemimpinan, kemahiran dwibahasa, etika dan semangat, dan identiti nasional (Kementerian Pendidikan Malaysia, 2013).

Walau bagaimanapun, masalah sosial dan jenayah, seperti rasuah moral, samseng, penyalahgunaan dadah, dan insiden buli sekolah-kanak-kanak, adalah masalah utama yang perlu ditangani, terutama di institusi pengetahuan seperti sekolah. Kesungguhan pemerintah untuk menyelesaikan masalah ini tercermin dalam tindakan positif Kementerian Pendidikan. Buli dalam kalangan murid sekolah menunjukkan bahawa pelbagai faktor mempengaruhi pembentukan keperibadian dan tingkah laku ini, tetapi dikatakan bahawa pengurusan disiplin pelajar sekolah, tingkah laku buli pelajar dan harga diri memainkan peranan utama dalam membentuk kualiti hidup pelajar (Mander et al., 2015). Di dalam sekolah, semua pelajar mesti mematuhi peraturan sekolah dan membendung masalah disiplin sekolah. Tuntasnya, kajian-kajian lepas juga ada membuktikan bahawa terhadap perkaitan antara pengurusan disiplin sekolah murid, tingkah laku buli murid dan estim kendiri murid terhadap kualiti kehidupan murid.

\section{Sorotan Literatur}

\section{Pengurusan Disiplin Sekolah}

Disiplin merujuk kepada kod tingkah laku baik yang dirumuskan oleh kumpulan masyarakat atau institusi untuk meningkatkan kehidupan masyarakat (Panduan Umum Disiplin Sekolah, 1981: 1). Lebih-lebih lagi, disiplin adalah cara berfikir yang teratur yang dapat memupuk rasional, keyakinan diri dan ketekunan seseorang. Di samping itu, disiplin di persekitaran sekolah adalah sekumpulan peraturan langsung yang mengatur tingkah laku pelajar melalui hukuman atau ganjaran. Kedua, disiplin dianggap sebagai bentuk latihan yang memupuk minda, badan, dan sikap pelajar di sekolah. Menurut Moles (1989), salah satu tujuan utama disiplin pelajar sekolah adalah untuk memastikan keselamatan dan kesejahteraan pelajar. Ini membolehkan jabatan pengurusan disiplin sekolah memberitahu pelajar mengenai peraturan sekolah yang telah diumumkan.

Di Malaysia, dapat dilihat bahawa tingkah laku ini menjadi semakin biasa, terutamanya di sekolah menengah (Yunus, 2012). Walaupun Kementerian Pendidikan, sekolah, dan sektor swasta telah mengambil berbagai langkah untuk memerangi tingkah laku tidak sihat ini di sekolah, kerana masalahnya semakin buruk, masalah disiplin pelajar kini membimbangkan. pelajar. Kadar penurunan nilai sosial dan kejadian salah laku pelajar meningkat dari tahun ke tahun. Kita juga sering dikejutkan dengan pelbagai insiden memalukan yang melibatkan pelajar. Kanak-kanak yang masih bersekolah terlibat dalam geng, penagihan dan pengedaran dadah, dan pelajar baru-baru ini terlibat dalam kecurian motosikal. Apabila ini berlaku, perhatian utama adalah guru, terutama guru subjek.

Karya Guru Penolong Kanan Hal Ehwal Pelajar (PK HEM) dan guru mata pelajaran hari ini sangat mencabar. Tetapi ini tidak bermaksud bahawa tugas mendisiplinkan pelajar hanya dapat diselesaikan oleh PK Hem dan guru disiplin, dan guru lain juga harus dipikul. Tugas guru sekarang tidak terhad kepada proses pengajaran dan pembelajaran2, tetapi juga harus mengambil tindakan dalam disiplin pelajar. Persekutuan Kebangsaan Profesion Perguruan (NUTP) mengeluarkan kenyataan meminta semua anggotanya mengabaikan masalah disiplin dan salah laku pelajar. Kejadian ini diumumkan oleh Menteri Pendidikan ketika itu, Datuk Seri Najib Tun Razak (Mingguan Malaysia, 24 Ogos 1997). 
Oleh itu, adalah mustahak untuk menghilangkan tanggapan bahawa guru percaya bahawa mereka tidak ada hubungannya dengan pelajar selepas permulaan sekolah, sehingga dapat melahirkan generasi yang cemerlang dan hebat yang menghadapi alaf baru. Sebenarnya, tugas mendisiplinkan pelajar tidak boleh dilaksanakan oleh guru semata-mata, tetapi harus dipikul oleh masyarakat, agensi kerajaan, NGO, dan ibu bapa. Adalah perlu untuk memupuk mentaliti "mempertahankan pakaian orang" untuk membendung ketiga-tiga masalah disiplin ini. Menurut Abdul Halim (1999), sekolah tidak seharusnya menangani masalah disiplin pelajar sahaja.

Ini dapat disimpulkan dari pernyataan ini bahawa semua guru adalah guru disiplin, dan mereka memang diakui oleh semua guru. Masalah yang dihadapi oleh guru adalah kerana kekangan masa, mereka keliru sama ada mahu memberi tumpuan kepada proses pengajaran dan pembelajaran atau untuk mendisiplinkan pelajar. Oleh itu, menurut Ibrahim (1990), guru mula menganggap tugas mendisiplinkan pelajar sebagai tugas mendisiplinkan guru, PK HEM dan pengetua sahaja. Pada masa yang sama, semua pihak yang terlibat dalam pengurusan disiplin juga menghadapi pelbagai cabaran dan rintangan, kerana mereka harus menghadapi semua pihak yang selalu mengkritik, memprotes, memfitnah, mengadu, mengancam, dan bertindak ganas ketika melaksanakan peraturan sekolah.

Kebiasaan seorang guru yang berdisiplin dibayangkan cukup kejam, garang, janggut tebal, suara serak, tidak ramah, dan sebagainya. Guru disiplin juga dianggap sebagai guru yang paling ditakuti di sekolah, malah lebih takut daripada guru besar. Pelbagai kisah terkini mengenai masalah yang berkaitan dengan disiplin sekolah. Ini kerana guru dengan keperibadian ini sering kali lebih dipercayai oleh sekolah dan dapat melaksanakan tugas berat ini dengan sempurna. Di samping itu, ia sering berkaitan dengan persepsi bahawa guru disiplin dianggap sebagai pelaksana disiplin dan disiplin sekolah. Jika sekolah melanggar disiplin, guru disiplin akan sering dikritik.

\section{Tingkah Laku Buli Murid}

Keperluan untuk memahami definisi buli adalah mustahak untuk menentukan dengan jelas dan tepat semua aspek buli pelajar. Donnell (2015) mendefinisikan buli sebagai tingkah laku pelajar atau sekumpulan pelajar yang mengganggu mangsa buli secara emosi atau fizikal untuk jangka masa yang panjang. Sanders dan Phye (2004) memandang buli sebagai penderaan atau menggoda individu, dengan tujuan untuk menyesuaikan mangsa dengan persekitaran baru. Pembuli juga membuli mangsa dengan menakut-nakutkan mereka. Orang yang melakukan buli biasanya akan melakukannya berulang kali, bukan hanya sekali (Sanders \& Phye, 2004).

Banyak kajian telah dilakukan untuk menentukan ciri-ciri pengganggu sekolah (Olweus, 2010). Pembuli adalah pelajar yang suka melawan dan mengolok-olokkan kanak-kanak lain. Menurut literatur, terdapat dua jenis pengganggu: pengganggu agresif dan pengganggu pasif. Pembuli yang agresif dilihat bertengkar, garang, agresif, dengan tahap keyakinan diri yang tinggi, dan kuat dan agresif secara fizikal. Buli jenis ini berasal dari orang yang mempunyai sikap toleransi yang rendah kerana beberapa kegagalan dan cenderung menjadi ganas berbanding dengan pelajar lain. Sikap pembuli terhadap tingkah laku agresif adalah positif. Ini bermaksud mereka suka melihat orang lain menderita. Mereka juga tidak mempunyai rasa empati dan percaya bahawa mangsa harus dibuli. Sebaliknya, sikap mereka terhadap sekolah adalah negatif.

Walaupun kebanyakan pengganggu tidak suka bersekolah, prestasi akademik mereka tidak semestinya rendah berbanding dengan pelajar lain (Slee \& Rigby, 1993). Oleh itu, buli tidak semestinya disebabkan oleh prestasi akademik yang rendah atau kegagalan dalam mata pelajaran sekolah. Di samping itu, dikatakan bahawa pengganggu tidak suka mengikuti peraturan atau mengakui bahawa tindakan mereka salah.

Pembuli mungkin lebih popular, lebih besar, lebih kuat, dan bersedia menguasai orang lain daripada rakan sebayanya. Mereka kurang bersimpati dengan mangsa dan tidak menyesal dengan tindakan yang telah mereka lakukan. Lebih daripada separuh dari gred bawah diganggu oleh kelas atas, sementara kelas atas diganggu oleh rakan sebaya mereka (Olweus, 1991). Berthold (1996) seterusnya mendapati bahawa pelajar yang dibuli cenderung merokok, meniru semasa peperiksaan, pergi ke sekolah dengan 
pistol, dan tinggal di rumah lebih dari dua jam selepas sekolah tanpa kawalan orang tua atau orang dewasa yang lain. Pembuli juga tidak mengakui bahawa mangsa mereka lebih lemah daripada mereka. Mereka fikir mereka melakukannya kerana mangsa mula-mula melakukan tingkah laku ini.

Berbanding dengan pelajar lelaki lain, pelajar lelaki buli dianggap lebih besar dan kuat. Secara umumnya, pelajar lelaki yang membuli dianggap sangat kuat dan agresif, tetapi sebenarnya mereka juga merasakan keselamatan diri mereka tidak terjamin. Rigby dan Slee (1993) mendapati bahawa pengganggu menunjukkan kegelisahan atau kebimbangan, merasa tidak selamat, dan tidak mempunyai harga diri yang rendah. Namun, Ma (2001) mendapati bahawa walaupun pelajar dengan kompleks rendah diri sering dibuli, pelajar ini juga sering membuli pelajar lain.

Beberapa kajian juga mendapati bahawa pelajar buli adalah pelajar popular yang selalu disokong dan menjaga hubungan baik dengan dua atau tiga rakan sebaya. Selalunya pelajar yang tidak diingini menjadi mangsa buli mereka. Olweus (1997) mendapati bahawa pengganggu perlu menguasai kuasa. Mereka gembira dengan kekuatan yang mereka miliki dan memperlakukan orang lain sebagai bawahan. Kerana kemiskinan keluarganya, pembuli jenis ini dilihat menunjukkan sikap memusuhi persekitarannya dan dilihat sanggup membiarkan orang lain menderita. Pembuli sering mengancam mangsa untuk memberikan wang atau barang bernilai lain.

Pada masa yang sama, penindasan yang agresif sering dilihat sebagai penghargaan dalam bentuk rasa hormat (Olweus, 1997). Biasanya, kerana corak tingkah laku yang ditunjukkan, pembuli menghadapi risiko tinggi untuk menyertai jenayah dan penggunaan dadah pada masa akan datang. Pada masa yang sama, penindasan yang agresif sering dilihat sebagai penghargaan dalam bentuk rasa hormat (Olweus, 1997). Biasanya, kerana corak tingkah laku yang ditunjukkan, pembuli menghadapi risiko tinggi untuk menyertai jenayah dan penggunaan dadah pada masa akan datang.

\section{Estim Kendiri Murid}

Definisi estim kendiri berkembang melalui sejarah yang panjang. Pada tahun 1890, William James mendefinisikan estim kendiri sebagai fenomena afektif dan proses dinamik yang dipengaruhi oleh kejayaan dan kegagalan dan dengan demikian membuka kepada peningkatan, atau perbandingan antara diri ideal (orang yang seharusnya saya) dan diri sebenar (orang yang saya sekarang) (James, 1983). Pada tahun 1963, Robert White melihat estim kendiri sebagai fenomena perkembangan tetapi berkembang secara beransur- ansur dipengaruhi oleh dan seterusnya mempengaruhi pengalaman dan tingkah laku, ia mempunyai dua sumber: sumber dalaman (pencapaian sendiri) dan sumber luaran (penegasan dari orang lain). Harga diri sebagai sikap (baik positif atau negatif) yang dimiliki individu terhadap diri mereka sendiri, dan bahawa ia adalah hasil pengaruh budaya, masyarakat, keluarga dan hubungan interpersonal (Rosenberg, 1979).

Pada tahun 1967, Stanley Coopersmith menggambarkan estim kendiri sebagai konstruk atau sifat yang diperoleh, iaitu, seseorang individu belajar betapa layaknya mereka pada mulanya dari ibu bapa. Pada tahun 1969, Nathaniel Branden menjelaskan estim kendiri sebagai keperluan asas manusia. Kekurangannya mempunyai akibat negatif yang serius seperti penyalahgunaan bahan, bunuh diri, kegelisahan dan kemurungan.

Pada tahun 1973, Lawrence menunjukkan bahawa estim kendiri adalah hasil dari serangkaian penilaian nilai yang dibuat oleh anak-anak ketika mereka dewasa, di mana mereka berusaha untuk menyusun idea yang mereka kembangkan mengenai kebolehan, sifat dan penampilan mereka. Mereka memperoleh satu persepsi terhadap bagaimana diri mereka diterima dan dihargai oleh orang dewasa. Oleh kerana interaksi dengan orang dewasa dan rakan sebaya yang signifikan, kanak-kanak membentuk kesan kemampuan dan kualiti peribadi yang dikagumi dan dihargai.

Estim kendiri, menurut Lawrence, adalah keseluruhan penilaian yang dibuat oleh kanak-kanak terhadap diri mereka sendiri dan tahap rasa hormat di mana mereka menganggap diri mereka sendiri. Oleh itu, estim kendiri dikonseptualisasikan sebagai perasaan dan sikap global yang dimiliki oleh kanak-kanak dan orang dewasa mengenai diri mereka sendiri. Secara umum, harga diri adalah 
penilaian seseorang terhadap nilai dirinya dan juga ditakrifkan sebagai nilai yang diberikan oleh setiap individu pada ciri, kebolehan, dan tingkah laku mereka sendiri (Von Der Haar, 2005). Dalam semua kes, estim kendiri adalah hasil daripada penilaian terhadap diri sendiri (Larsen, 2008), dan ukuran harga diri dari banyak bidang mempunyai kaitan sederhana; seseorang yang mempunyai harga diri yang tinggi di satu kawasan juga cenderung mempunyai harga diri yang tinggi di kawasan lain juga. Estim kendiri juga dapat ditakrifkan sebagai jumlah harga diri dan kecekapan diri yang bersepadu (Mruk, 2006). Ini bermaksud bahawa pelajar yang mempunyai estim kendiri yang positif adalah mereka yang merasa yakin terhadap diri sendiri.

Estim kendiri telah dianggap penting bagi kehidupan individu sejak beberapa dekad yang lalu. Robson (1988) menyatakan bahawa estim kendiri adalah sifat penting bagi seseorang individu, kerana ia akan mempengaruhi tingkah laku setipa individu khususnya murid. Individu dengan estim kendiri yang mencukupi hanya merasakan bahawa mereka adalah orang yang bernilai; mereka menghormati diri mereka untuk apa adanya, tetapi tidak mengagumi diri mereka sendiri dan juga tidak mengharapkan orang lain mengagumi mereka.

Lebih-lebih lagi, harga diri berkorelasi secara signifikan dengan tanggungjawab individu; pengambilan tanggungjawab sama ada untuk diri sendiri atau orang lain menunjukkan adanya keyakinan diri dan keselamatan diri yang cukup untuk membolehkan seseorang individu memikul peranan tanggungjawab (Horrocks \& Jackson, 1972). Crocker dan Park (2003) menunjukkan bahawa estim kendiri dapat mendorong seseorang individu untuk mencari kejayaan dan mengelakkan kegagalan dengan cara yang tidak berbahaya bagi diri mereka sendiri atau orang lain. Pernyataan ini mengetengahkan beta pentingnya estim kendiri dalam kehidupan seseorang individu untuk menentukan masa depan seseorang. Sebaliknya, estim kendiri yang sangat tinggi, dalam beberapa keadaan, dinyatakan sebagai faktor kecenderungan bunuh diri (Martin, Richardson, Bergen, Roeger, \& Allison, 2005).

Dalam konteks sekolah, estim kendiri adalah konsep pusat yang berkaitan dengan pencapaian akademik, fungsi sosial dan psikopatologi kanak-kanak dan remaja (Bos, Muris, Mulkens, \& Schaalma, 2006). Estim kendiri penting untuk memberikan motivasi yang diperlukan agar berjaya dalam bidang akademik (Ferkany, 2008).

Estim kendiri murid mungkin menjadi sebahagian yang menyokong matlamat akademik sekolah, tanpa menjadikannya sebagai keutamaan pendidikan (Ferkany, 2008). Sebaliknya, estim kendiri dapat dilihat sebagai konstruk yang menjadi perantara antara kemampuan dan pencapaian; estim kendiri boleh mempengaruhi pencapaian seterusnya, dan prestasi boleh mempengaruhi tahap estim kendiri seterusnya (Mruk, 2006). Oleh itu murid-murid dengan estim kendiri yang rendah kurang berjaya di sekolah (Mann, Hosman, Schaalma, \& De Vries, 2004). Berkenaan dengan fungsi sosial, pelajar dengan harga diri yang rendah biasanya kurang diterima oleh rakan sebaya mereka (Donders \& Verschueren, 2004).

Selanjutnya, banyak kajian menunjukkan bahawa harga diri yang rendah berkaitan dengan psikopatologi kanak-kanak, termasuk kegelisahan, kemurungan dan patologi makan (Beck, Brown, Steer, Kuyken, \& Grisham, 2001). Dengan kata lain, estim kendiri pelajar adalah sifat penting yang perlu diberi perhatian berkaitan dengan pencapaian akademik. Pelajar yang mempunyai estim kendiri yang positif cenderung untuk berusaha mencapai pencapaian akademik yang lebih tinggi, dan seterusnya, pencapaian akademik yang lebih tinggi cenderung untuk meningkatkan estim kendiri mereka. Pelajar dengan tahap estim kendiri yang rendah cenderung menghadapi masalah sosial atau disiplin.

\section{Kualiti Kehidupan Murid}

Kualiti kehidupan murid ini dapat didefinisikan sebagai tingkah laku buli murid seseorang untuk mencapai makna kehidupan dengan kepuasan secara sihat (Stegeret al., 2006). Terdapat pelbagai takrif tentang makna kehidupan dalam bidang psikologi, termasuklah kepaduan dalam hidup murid (Battista 
\& Almond, 1973), matlamat yang terarah atau tujuan (Ryff \& Singer, 1998) serta kepentingan ontologi kehidupan daripada perspektif murid yang menjalani kehidupan (Crumbaugh \& Maholick, 1964).

Selain itu, penyelidik seperti Allport (1961) dan Seligman (2002) pula melihat perolehan makna kehidupan berlaku menerusi usaha jangkauan kendiri individu untuk mencipta makna. Meskipun terdapat perbezaan dari segi takrif dan cara memperoleh makna kehidupan, para penteori pada asasnya bersetuju bahawa makna kehidupan sangat penting. Kehidupan yang bermakna kerap dikaitkan dengan kehidupan yang autentik (Kenyon, 2000), dan dalam teori sifat murni kualiti kehidupan yang menekankan perkembangan peribadi murid dan kekuatan psikologi yang menjangkau perasaan yang selesa atau nyaman, makna kehidupan sangat penting sama ada sebagai komponen yang kritikal (Ryff \& Singer, 1998) atau terhasil daripada usaha murid memaksimumkan potensi dirinya (sebagai contoh Deci \& Ryan, 2000; Maslow, 1971). Frankl (1963) menegaskan bahawa manusia diberikan fitrah untuk memacu makna, iaitu mempunyai tekad dalam diri untuk mencari makna dan kepentingan dalam kehidupan mereka. Kegagalan mereka untuk memperoleh makna dalam kehidupan boleh mengundang rasa kecewa.

Selain itu, Lazaro-Visa (2019) mendapati bahawa terdapat hubungan yang signifikan antara sekolah dengan kualiti kehidupan murid. Kajian ini melibatkan 647 orang murid di Sepanyol. Dapatan kajian menunjukkan pengaruh pengurusan disiplin sekolah telah memberi kesan kualiti kehidupan murid di sekolah berasaskan kepuasan kehidupan individu yang mengambil kira ciri-ciri seperti pembaikan emosi dan harga diri. Di samping itu, kajian Espelage dan Hong (2019) mendapati pengurusan disiplin sekolah mempunyai kaitan dengan pelbagai dimensi sekolah seperti membuli sehingga dapat menjejaskan kualiti kehidupan murid di sekolah.

Han et al. (2017) telah menjalankan satu kajian yang bertajuk dalam kalangan murid-murid sekolah awam yang melibatkan sebanyak 14536 orang murid di negara China, iaitu merangkumi 11 buah wilayah autonomi di luar bandar dan bandar China. Hasil kajian ini mendapati terdapat kolerasi antara pembuli dengan penyesuaian psikososial. Kajian ini mendapati tingkah laku buli murid di sekolah mempengaruhi kualiti kehidupan murid melalui sekolah sebagai penyumbang utama.

Kesemua enam faktor pengurusan disiplin murid sekolah berkaitan dengan kualiti kehidupan murid. Perhubungan ini secara tidak langsung (dengan pengecualian sokongan guru, kaitan sekolah dan kepelbagaian yang menyokong) yang diketengahkan melalui pengertian identiti etnik dan moral murid, ketahanan diri dan kepuasan hidup. Kajian Sari (2017) yang melibatkan 40 orang murid MTs Al-Halim di Sipogu menunjukkan terdapat kolerasi antara hubungan pengurusan disiplin sekolah, tingkah laku buli murid terhadap kualiti murid di sekolah. Hal ini menjelaskan 41.6 peratus terdapat kolerasi dengan pengurusan disiplin sekolah sebagai penyumbang pola asuh permisif dalam tingkah laku buli murid.

Penilaian kualiti hidup atau lebih dikenali sebagai kesejahteraan hidu sukar diukur, dan tidak ada definisi yang diterima secara universal. Pada masa lalu, kebanyakan penyelidik hanya mengira kualiti kehidupan manusia berdasarkan satu dimensi seperti fungsi fizikal, fungsi ekonomi atau seksual. Walau bagaimanapun, kebanyakan penyelidik kini berusaha untuk mengembangkan lagi definisi kualiti hidup ini. Kualiti hidup di Malaysia didefinisikan sebagai termasuk pembangunan peribadi, gaya hidup sihat, pencapaian dan akses percuma ke pengetahuan dan taraf hidup yang melebihi keperluan asas dan psikologi individu, mencapai tahap kesejahteraan sosial yang memenuhi standard kebangsaan. keinginan. Apabila masyarakat beralih ke persekitaran hidup yang umumnya lebih baik, dianggap bahawa kualiti hidupnya telah meningkat.

Penting untuk memahami kualiti hidup, terutama di sektor penjagaan kesihatan di mana kaedah ekonomi tidak dipertimbangkan. Kualiti hidup adalah tahap kebahagiaan dalam hidup yang dialami oleh individu atau sekumpulan orang. Kualiti hidup bukanlah konsep yang nyata dan tidak dapat diukur secara langsung. Ia mengandungi dua komponen, yang pertama berasal dari badan, termasuk kesihatan, diet, pencegahan penyakit dan menghilangkan rasa sakit. Komponen kedua pada asasnya adalah psikologi. Aspek-aspek ini merangkumi tekanan, kegelisahan, kepuasan, dan keadaan emosi 
negatif atau positif. Tidak dapat meramalkan kualiti hidup, terutama bagi individu. Gabungan ciri-ciri yang ada pada diri individu jarang mendorong individu itu berpuas hati dengan orang lain.

Mengikut definisi Ahmad et al. (2020), kualiti hidup didefinisikan sebagai persepsi individu mengenai statusnya dalam kehidupan dalam persekitaran budaya dan sistemik. Dalam persekitaran ini, ia berkait rapat dengan tujuan, harapan, tahap dan beban. Sebilangan orang mengatakan bahawa kebahagiaan dalam hidup adalah sesuatu yang membuat orang merasa menarik dan bahagia, dan bahawa hidup mereka sangat bermakna. Terdapat buku-buku yang menggambarkan bahawa kebahagiaan dalam hidup sebenarnya merupakan usaha untuk mengatasi masalah dan meningkatkan kualiti hidup manusia agar berada dalam keadaan hidup selamat, sihat dan selesa secara fizikal, sosial dan psikologi (Prime et at., 2020).

Menurut laporan yang dikeluarkan oleh Jabatan Kesihatan dan Perkhidmatan Manusia A.S. (2018), kualiti hidup adalah nilai berdasarkan jangka hayat yang diubah atau diubah kerana penyakit, kecederaan, rawatan dan gangguan yang dipengaruhi oleh polisi, status fungsional, persepsi, dan peluang sosial. Mereka juga menunjukkan bahawa penilaian sering membantu meningkatkan kualiti hidup. Contohnya termasuk fungsi fizikal, fungsi emosi atau mental, fungsi sosial, ketidakpuasan fizikal dan fizikal, dan laporan global mengenai kualiti hidup. Konsep kebahagiaan atau kualiti hidup tidak hanya diukur dengan penilaian material, seperti pemilikan rumah, kenderaan, pendidikan tingkat tinggi, tetapi juga aspek bukan material seperti kesejahteraan hidup dan sebagainya.

\section{Kesimpulan}

Penekanan dalam kerangka konseptual kajian ini juga berkait rapat dengan kualiti kehidupan murid di sekolah secara langsung disebabkan implikasi interaksi mempengaruhi kualiti kehidupan murid seharian di sekolah. Kualiti kehidupan bermakna mesti melalui proses sifat agreeableness iaitu bersikap degil, suka bermusuhan, syak wasangka dan ini menjadi sikap negatif yang akan mendorong kepada masalah kualiti kehidupan murid di sekolah. Hasil ini dapat dilihat dan dikesan apabila kewujudan kepuasan merupakan sebahagian proses mental dan entiti kognitif yang menjurus kepada makna kehidupan murid di sekolah secara realiti. Selain itu, sifat neuroticism iaitu murid memiliki personaliti ini kecenderungan mengalami emosi negatif seperti kebimbangan, marah, tekanan sering beranggapan situasi normal yang mengancam dan sering merasa kecewa. Kesannya dapat dilihat dan dikesan apabila kualiti murid dapat diukur melalui nilai disiplin mereka di sekolah. Kepuasan murid dapat diukur dengan disiplin mereka di sekolah kerana kualiti kehidupan murid di sekolah dapat mempengaruhi tahap pemikiran murid untuk mematuhi peraturan dan disiplin di sekolah maka tidak berlaku kepuasan melalui tindakan membuli.

\section{Rujukan}

Ahmad, A. A., \& Ambotang, A. S. B. (2020). Pengaruh kecerdasan emosi, kecerdasan spiritual dan persekitaran keluarga terhadap stres akademik murid sekolah menengah. Malaysian Journal of Social Sciences and Humanities (MJSSH), 5(5), 12-23.

Allport, G. W. (1961). Values and our youth. Teachers College Record.

Anglim, M., Sarkar, M., Byrne, P., Power, L., Fitzpatrick, C., Boylan, C., \& Morgan, S. (2010). Are suicidal phenomena in children different to suicidal phenomena in adolescents? A six-year review. Child and Adolescent Mental Health, 15(4), 197-203.

Battista, J., \& Almond, R. (1973). The development of meaning in life. Psychiatry, 36(4), 409-427.

Beck, A. T., Brown, G. K., Steer, R. A., Kuyken, W., \& Grisham, J. (2001). Psychometric properties of the beck self-esteem scales. Behaviour research and therapy, 39(1), 115-124.

Berthold, P. (1996). Control of bird migration. Springer Science \& Business Media.

Bos, A. E., Muris, P., Mulkens, S., \& Schaalma, H. P. (2006). Changing self-esteem in children and adolescents: A roadmap for future interventions. Netherlands Journal of Psychology, 62(1), 2633. 
Crocker, J., \& Park, L. E. (2003). Seeking self-esteem: Construction, maintenance, and protection of self-worth.

Crumbaugh, J. C., \& Maholick, L. T. (1964). An experimental study in existentialism: The psychometric approach to Frankl's concept of noogenic neurosis. Journal of clinical psychology, 20(2), 200-207.

Deci, E. L., \& Ryan, R. M. (2000). The" what" and" why" of goal pursuits: Human needs and the selfdetermination of behavior. Psychological inquiry, 11(4), 227-268.

Donders, W., \& Verschueren, K. (2004). Zelfwaardering en acceptatie door leeftijdgenoten. Kind en adolescent, 25(2), 45-54.

Espelage, D., \& Hong, J. S. (2019). A meta-analytic review of school-based anti-bullying programs with a parent component. International journal of bullying prevention, 1(1), 32-44.

Ferkany, M. (2008). The educational importance of self-esteem. Journal of Philosophy of Education, 42(1), 119-132.

Frankl, L. (1963). Self-preservation and the development of accident proneness in children and adolescents. The psychoanalytic study of the child, 18(1), 464-483.

Galanou, C., Galanakis, M., Alexopoulos, E., \& Darviri, C. (2014). Rosenberg self-esteem scale Greek validation on student sample. Psychology, 5(8), 819-823.

Gonçalves, F. G., Heldt, E., Peixoto, B. N., Rodrigues, G. A., Filipetto, M., \& Guimarães, L. S. P. (2016). Construct validity and reliability of Olweus Bully/Victim Questionnaire - Brazilian version. Psicologia: Reflexao e Critica, 29(1). https://doi.org/10.1186/s41155-016-0019-7

Halim, A. (1999). Steinstrasse: a comparison of incidence with and without $\mathbf{J}$ stenting and the effect of $\mathrm{J}$ stenting on subsequent management. BJU international, 84(6), 618-621.

Han, Y., Cheng, X., Fu, S., \& Zarifis, A. (2017). Investigating the individual trust and school performance in semi-virtual collaboration groups. Information Technology \& People.

Horrocks, J. E., \& Jackson, D. W. (1972). A theory of self-process and role behavior.

James, W. (1983). Talks to Teachers on Psychology and to Students on Some of Life's Ideals. Harvard University Press.

Kalaichalvi, A., Patchaippan, P., \& Bahru, J. Pengurusan Disiplin Pelajar Di Sekolah Menengah Daerah Kulaijata, Johor.

Kenyon, G. M. (2000). Philosophical foundations of existential meaning. Exploring existential meaning: Optimizing human development across the life span, 7-22.

Larsen, R. J. (Eds.). (2008). The science of subjective well-being. Guilford Press.

Lázaro-Visa. (2019). Bullied adolescent's life satisfaction: personal competencies and school climate as protective factors. Frontiers in psychology, 10, 1691.

Ma, X. (2001). Bullying and being bullied: To what extent are bullies also victims?. American Educational Research Journal, 38(2), 351-370.

Malaysia, K. P. (2017). Kurikulum standard sekolah menengah. Bahagaian Pembangunan Kurikulum. Malaysia, P. P. P., \& Laporan Prestasi, P. M. R. (2013). Kementerian Pendidikan Malaysia. Draf Kurikulum Standard Sekolah.

Mander, D. J., Lester, L., \& Cross, D. (2015). The social and emotional well-being and mental health implications for adolescents transitioning to secondary boarding school. International Journal of Child and Adolescent Health, 8(2), 131.

Mann, M. M., Hosman, C. M., Schaalma, H. P., \& De Vries, N. K. (2004). Self-esteem in a broadspectrum approach for mental health promotion. Health education research, 19(4), 357-372. Mann, M. M., Hosman, C. M., Schaalma, H. P., \& De Vries, N. K. (2004). Self-esteem in a broad-spectrum approach for mental health promotion. Health education research, 19(4), 357372.

Martin, G., Richardson, A. S., Bergen, H. A., Roeger, L., \& Allison, S. (2005). Perceived academic performance, self-esteem and locus of control as indicators of need for assessment of adolescent suicide risk: implications for teachers. Journal of adolescence, 28(1), 75-87.

Maslow, A. H. (1971). Self-actualization. Big Sur Recordings

Mruk, C. J. (2006). Self-esteem research, theory, and practice: Toward a positive psychology of selfesteem. Springer Publishing Company.

O'Donnell, M. B. (2015). The impact of bullying and act variables on meaning in life for adolescents. Doctoral dissertation, Colorado State University. 
Olweus, D. (1997). Bully/victim problems in school: Facts and intervention. European journal of psychology of education, 12(4), 495-510.

Phye, G. D., \& Sanders, C. (2004). Bullying: Implications for the classroom. Elsevier.

Prime, H., Wade, M., \& Browne, D. T. (2020). Risk and resilience in family well-being during the COVID-19 pandemic. American Psychologist, 75(5), 631.

Robson, P. J. (1988). Self-esteem-a psychiatric view. The British Journal of Psychiatry, 153(1), 6-15.

Ryff, C. D., \& Singer, B. (1998). The role of purpose in life and personal growth in positive human health. Lawrence Erlbaum Associates Publishers.

Sari, R. F. (2017). Pengaruh Disiplin Kerja, Kepuasan Kerja dan Motivasi Kerja Terhadap Komitmen Organisasi Guru SMP Negeri di Kecamatan Medan Kota, Doctoral dissertation, UNIMED.

Seligman, M. E. (2002). Positive psychology, positive prevention, and positive therapy. Handbook of positive psychology, 2(2002), 3-12.

Stapa, Z., Ismail, A. M., \& Yusuf, N. (2012). Faktor persekitaran sosial dan hubungannya dengan pembentukan jati diri (Social environmental factors and their relation to identity formation). Jurnal Hadhari: An International Journal, 155-172.

Steger, M. F., Frazier, P., Oishi, S., \& Kaler, M. (2006). The meaning in life questionnaire:Assessing the presence of and search for meaning in life. Journal of Counseling Psychology, 53(1), 80-89.

Von der Haar, C. M. (2005). Social psychology: A sociological perspective. Pearson Education New Zealand.

Yunus, A. Z. (2012). Tahap pengetahuan dan amalan pengurusan disiplin pelajar dalam kalangan guru disiplin di Sekolah Menengah Kebangsaan daerah Segamat. Doctoral dissertation, Universiti Teknologi Malaysia. 